Finisterra, XXXVI, 71, 2001, pp. 49-60

\title{
DAILY MINIMUM AIR TEMPERATURES IN THE SERRA DA ESTRELA, PORTUGAL
}

\author{
CARLA MORA ${ }^{1}$ \\ Gonçalo Teles Vieira ${ }^{2}$ \\ MARIA JoÃo AlCOFORAdo ${ }^{3}$
}

\begin{abstract}
The Serra da Estrela is part of the Iberian Central Cordillera and is the highest mountain in Portugal (1,993 m ASL). The Torre-Penhas Douradas and Alto da Pedrice-Malhada Alta plateaus with altitudes between 1,400 and 1,993m, which are separated by the Alforfa and Zêzere valleys dominate the highest part of the range. The central massif is dissected by several glacially sculpted valleys that originate reliefs from 200 to $700 \mathrm{~m}$. This morphological diversity controls to a great extent the local climates of the mountain. Nine air temperature data loggers were installed in contrasting topographic situations, with special emphasis to valley floors and interfluve sites. Data collection was made each 2-hours from 27th December 1999 to 27th March 2000. Minima temperature most of the times occurs at 7 UTC. The minimum air temperature patterns based on the data from the nine sites were classified using k-means. Two contrasting events were chosen for the centroids of the classification. Cluster 1 represents the stable events with thermal inversions in the valleys and higher temperature in the interfluves. The valley floors at higher altitudes present lower temperatures than the ones at lower positions. Cluster 2 groups the unstable episodes with more turbulence and a temperature decrease controlled by altitude. In this group temperature does not depends on the topographic position.
\end{abstract}

Key words: local climate, minimum temperatures, thermal patterns, cold air drainage, Serra da Estrela.

Resumo - as temperaturas mínimas do ar na Serra da Estrela, Portugal A Serra da Estrela faz parte da Cordilheira central e é a montanha mais alta de Portugal Continental. As características morfológicas da serra traduzem-se na existência de dois sectores planálticos principais (Torre-Penhas Douradas e Alto da Pedrice-Malhada Alta) a altitudes situadas entre 1400 e 1993 m. A estas unidades altas contrapõem-se vales profundos, que ligam o interior da serra às áreas limítrofes. São estas características morfológicas que determinam, em larga medida, os climas locais da serra. Para o estudo dos padrões térmicos foram instalados 9 registadores automáticos de temperatura em posições topográficas distintas

1 Investigadora do Centro de Estudos Geográficos, Universidade de Lisboa. E-mail: cmora@ceg.ul.pt

2 Investigador do Centro de Estudos Geográficos e Assistente da Universidade de Lisboa. E-mail: gtvieira@ceg.ul.pt

3 Investigadora do Centro de Estudos Geográficos e Professora Associada da Universidade de Lisboa. E-mail: mjalcoforado@mail.telepac.pt 
(fundos de vale e topos). Os dados foram registados de duas em duas horas de 27 de Dezembro de 1999 a 27 de Março de 2000. A temperatura mínima diária ocorre frequentemente cerca das 7 UTC, o que levou a seleccionar para análise as observações a esta hora. Os padrões térmicos foram classificados usando a técnica de k-means. A análise teve como ponto de partida a identificação de dois dias com padrões térmicos contrastados, que foram usados como centróides para a classificação. O cluster 1 separou os dias caracterizados por situações estáveis, com acumulação de ar frio nos fundos de vale. As temperaturas são, nesses casos, mais baixas nas áreas deprimidas e vales situados a maior altitude. O cluster 2 agrupou os dias marcados por instabilidade. As temperaturas mais baixas ocorrem nas áreas mais elevadas independentemente da posição topográfica.

Palavras-chave: clima local, temperatura mínima, padrões térmicos, acumulação de ar frio, Serra da Estrela.

\section{INTRODUCTION}

The Serra da Estrela is the highest mountain massif in Portugal $\left(40^{\circ} 20^{\prime} \mathrm{N}\right.$, $7^{\circ} 35^{\prime} \mathrm{W}, 1,993 \mathrm{~m} \mathrm{ASL}$ ) and is part of the Iberian Central Cordillera. It is a granite horst aligned in a NE-SW direction. It presents stair-like plateaus deeply dissected by glacially sculpted valleys. The plateaus are located above $1,400 \mathrm{~m}$ ASL and up to the summit. Major valley floors range from 700 to $1,600 \mathrm{~m} \mathrm{ASL}$ and the slopes are usually steep, with altitude differences from 200 to $700 \mathrm{~m}$.

No long-term climate data exists for the highest parts of the mountain and the local climates are still poorly understood. VIEIRA and Mora (1998) estimated a mean annual temperature of 3 to $4^{\circ} \mathrm{C}$ for the highest areas. Precipitation exceeds 2,500 mm (DAVEAU, 1977) and part of it falls as snow (no data available). Summer dryness induces a Mediterranean character to the climate. Phytogeographic elements suggest that the Serra da Estrela is in the transition between the Mediterranean and Atlantic influence (JANSEN and SEQueIRA, 1999).

A significant topoclimatic differentiation (i.e. formation of cold air lakes in small basins) is emphasised by the original imprint of the Pleistocene glacial erosion (i.e. hanging valleys, erosional basins and cirques). Research on the local climates is therefore a major element in the framework of an interdisciplinary project that focuses on the landscape dynamics (ESTRELA). Special attention is being given to the study of the thermal patterns under different atmospheric conditions.

\section{MATERIAL AND METHODS}

Nine single-channel Tiny Talk II ${ }^{\circledR}$ data loggers (VIEIRA et al., 2000) were installed in sites chosen to show the influence of topography and altitude on air temperatures (fig. 1). A special emphasis was attempted on obtaining data for the plateaus, as well as for the valley floors. In order to study the highest and 


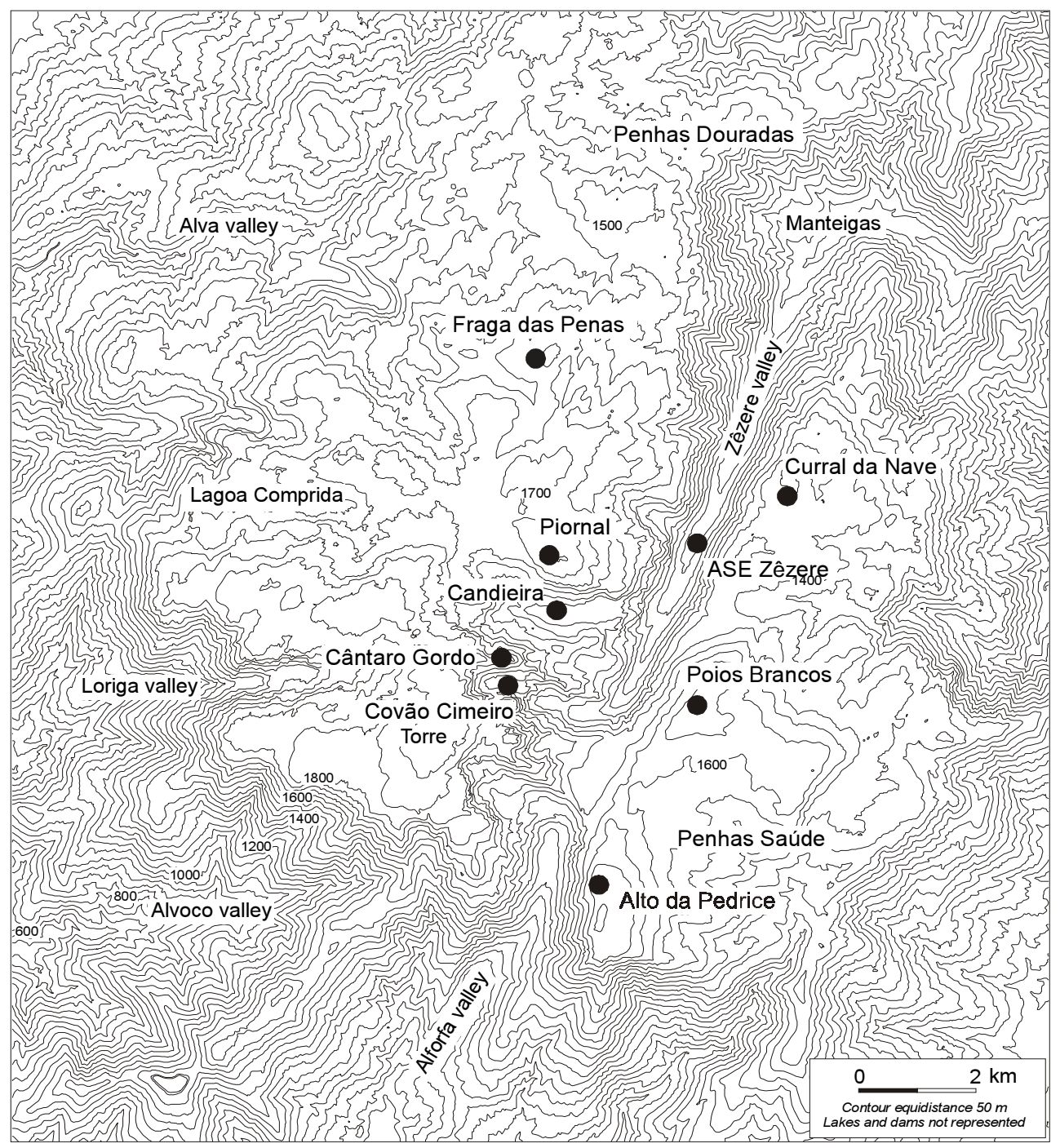

FIG. 1 - Location of the air temperature data loggers

FIG. 1 - Localização dos postos de medição da temperatura do ar

more exposed sites, several localities were chosen in the plateaus and summit areas (Cântaro Gordo, Piornal, Fraga das Penas, Alto da Pedrice and Poios Brancos). Sheltered sites in valley floors and small depressions in the plateaus were also monitored (Covão Cimeiro, Candieira, ASE Zêzere and the Curral da Nave).

The loggers were installed in open spaces at a height of $120 \mathrm{~cm}$ from the ground, far from trees and significant obstacles. In the next years stations with 
redundant results will be moved into other unmonitored locations, in order to allow a better estimation of the temperature patterns.

The main objective of this note is to present the minimum temperature patterns. Data was collected at 2-hour intervals between 27/12/99 and 27/3/00. The data analysis indicated that 7 UTC is the time in which the daily minimum temperatures occured more frequently. This hour was therefore chosen for a more detailed study.

In order to assess the occurrence of cold air accumulations, the temperature differences between each station and the one placed in Piornal were computed. Piornal is located on a plateau (fig. 2) and shows a similar regime and small temperature differences from other plateau or summit sites (table I). However when comparing its values with those from valley sites the correlation diminishes. That fact is due to the frequent temperature inversions with colder valley floors. Negative temperature diferences between Candieira (valley site) and Piornal correspond to cold air accumulation events, while positive diferences occur when temperature is controlled by the adiabatic lapse-rate.

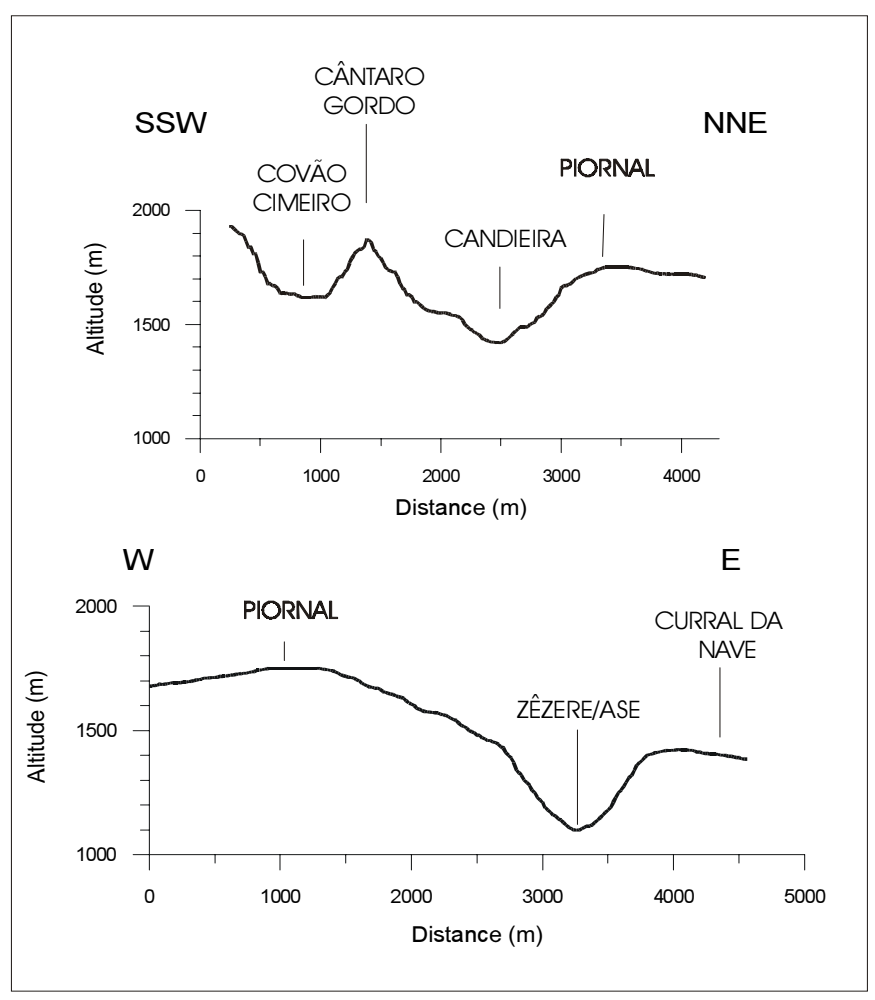

Fig. 2 - Topographic position of the Piornal reference station

Fig. 2 - Posição topográfica da estação de referência do Piornal 
TABLE I - Correlation coefficients (R) for the air temperatures at 7UTC (all statistically significant). Note the more significant coefficients between similar topographic sites. (Valley stations in bold)

QUADRO I-Coeficientes de correlação $(R)$ para as temperaturas às 7UTC nos vários locais estudados (todos os resultados são estatisticamente significativos). Notar o maior valor das correlações entre as estações com a mesma posição topográfica. (As estações de fundo de vale estão a negrito)

\begin{tabular}{|l|c|c|c|c|c|c|c|c|}
\hline & $\begin{array}{c}\text { Alto } \\
\text { Pedrice }\end{array}$ & $\begin{array}{c}\text { ASE } \\
\text { Zêzere }\end{array}$ & Candieira & $\begin{array}{c}\text { Cântaro } \\
\text { Gordo }\end{array}$ & $\begin{array}{c}\text { Covão } \\
\text { Cimeiro }\end{array}$ & $\begin{array}{c}\text { Curral } \\
\text { da Nave }\end{array}$ & $\begin{array}{c}\text { Fraga } \\
\text { Penas }\end{array}$ & $\begin{array}{c}\text { Poios } \\
\text { Brancos }\end{array}$ \\
\hline Ase Zêzere & 0.68 & & & & & & & \\
Candieira & 0.64 & 0.81 & & & & & & \\
Cântaro Gordo & 0.93 & 0.55 & 0.50 & & & & & \\
Covão Cimeiro & 0.81 & 0.70 & 0.87 & 0.72 & & & & \\
Curral da Nave & 0.66 & 0.89 & 0.87 & 0.54 & 0.79 & & & \\
Fraga Penas & 0.90 & 0.70 & 0.62 & 0.91 & 0.77 & 0.71 & & \\
poios Brancos & 0.94 & 0.70 & 0.65 & 0.96 & 0.79 & 0.58 & 0.94 & \\
Piornal & 0.92 & 0.57 & 0.52 & 0.94 & 0.73 & 0.69 & 0.94 & 0.94 \\
\hline
\end{tabular}

The days with the minima dominated by cold air drainage conditions and with the lowest temperatures in the valleys are easily separated from the ones with the lowest temperatures in the highest sites.

The daily temperature differences between each site and Piornal at 7UTC (hour with the maximum frequency of the daily minima) for the whole studyperiod were compiled in a table with 92 individuals (dates) and 8 variables (monitoring sites with the exception of Piornal, which shows a constant zero value). A k-means analysis (HARTIGAN, 1975) was selected to classify the days according to different air temperature patterns. An episode with cold air accumulation and another one with a lapse rate controlled by altitude were chosen as centroids for the determination of 2 clusters.

In order to assess the factors that influence the differentiation between the two clusters, daily synoptical charts and data from the meteorological station of the Instituto de Meteorologia located in Penhas Douradas (1,360 m ASL) were also analysed. 
TABLE II - Summary of the temperature data measured at 7 UTC during the winter of 1999/2000 in the Serra da Estrela

QUADRO II - Síntese dos dados registados às 7 UTC durante o Inverno de 1999/ 2000 na Serra da Estrela

\begin{tabular}{lccccc} 
TOTAL & \multicolumn{5}{c}{ PLATEAU / MOUNTAIN TOP SITES } \\
& Alto Pedrice & \multicolumn{1}{c}{ Cant. Gordo } & Fraga Penas & Piornal & Poios Brancos \\
& $1735 \mathrm{~m}$ & $1875 \mathrm{~m}$ & $1630 \mathrm{~m}$ & $1750 \mathrm{~m}$ & $1675 \mathrm{~m}$ \\
\cline { 2 - 6 } Average Temp. ${ }^{\circ} \mathrm{C}$ & 0,5 & 0,8 & 0,8 & 0,8 & $-0,6$ \\
Abs. Max. Temp. ${ }^{\circ} \mathrm{C}$ & 6,9 & 7,3 & 8,4 & 7,3 & 6,2 \\
Abs. Min. Temp. ${ }^{\circ} \mathrm{C}$ & $-9,2$ & $-8,7$ & $-7,2$ & $-8,2$ & $-10,2$ \\
& & & & & \\
10th Percentile & $-4,4$ & $-4,4$ & $-4,3$ & $-4,0$ & $-5,8$ \\
25th Percentile & $-2,2$ & $-1,9$ & $-1,5$ & $-1,8$ & $-3,5$ \\
median & 1,7 & 1,9 & 1,1 & 1,9 & $-0,1$ \\
75th Percentile & 3,1 & 3,6 & 3,5 & 3,5 & 2,3 \\
90th Percentile & 4,3 & 5,0 & 5,0 & 4,6 & 3,9 \\
Standard-desviation & 3,6 & 3,8 & 3,6 & 3,6 & 3,7 \\
& & & & & \\
Nr. Days min $<5^{\circ} \mathrm{C}$ & 88 & 85 & 84 & 86 & 90 \\
Nr. Days min $<0^{\circ} \mathrm{C}$ & 36 & 36 & 37 & 38 & 48 \\
Nr. Days min $<-5^{\circ} \mathrm{C}$ & 8 & 8 & 7 & 8 & 11
\end{tabular}

\begin{tabular}{cccc} 
ASE Zêzere & Candieira & \multicolumn{2}{c}{ VALLEY SITES } \\
Covão Cimeiro & Curral da Nave \\
$1080 \mathrm{~m}$ & $1420 \mathrm{~m}$ & $1620 \mathrm{~m}$ & $1425 \mathrm{~m}$ \\
\hline 0,9 & $-1,1$ & $-0,7$ & $-1,4$ \\
8,8 & 8,0 & 6,9 & 6,2 \\
$-6,7$ & $-12,9$ & $-14,6$ & $-11,8$ \\
$-4,3$ & $-7,7$ & $-6,3$ & $-6,7$ \\
$-1,8$ & $-4,4$ & $-4,4$ & $-4,0$ \\
1,1 & $-1,0$ & $-0,6$ & $-1,4$ \\
3,5 & 2,3 & 3,1 & 1,2 \\
5,4 & 5,4 & 4,6 & 3,9 \\
3,7 & 4,9 & 4,5 & 4,1 \\
& & & \\
80 & 80 & 86 & 87 \\
35 & 56 & 49 & 58 \\
4 & 20 & 18 & 16
\end{tabular}

CLUSTER 1

PLATEAU / MOUNTAIN TOP SITES

\begin{tabular}{|c|c|c|c|c|c|}
\hline & $\begin{array}{c}\text { Alto Pedrice } \\
1735 \mathrm{~m}\end{array}$ & $\begin{array}{c}\text { Cant. Gordo } \\
1875 \mathrm{~m}\end{array}$ & $\begin{array}{c}\text { Fraga Penas } \\
1630 \mathrm{~m}\end{array}$ & $\begin{array}{l}\text { Piornal } \\
1750 \mathrm{~m}\end{array}$ & $\begin{array}{c}\text { Poios Brancos } \\
1675 \mathrm{~m}\end{array}$ \\
\hline Average Temp. ${ }^{\circ} \mathrm{C}$ & 1,0 & 2,0 & 1,4 & 1,9 & $-0,1$ \\
\hline Abs. Max. Temp. ${ }^{\circ} \mathrm{C}$ & 6,2 & 7,3 & 8,4 & 7,3 & 5,8 \\
\hline Abs. Min. Temp. ${ }^{\circ} \mathrm{C}$ & $-9,2$ & $-8,7$ & $-7,2$ & $-8,2$ & $-10,2$ \\
\hline 10th Percentile & $-3,1$ & $-2,7$ & $-3,0$ & $-2,6$ & $-4,4$ \\
\hline 25th Percentile & $-2,1$ & $-0,4$ & $-0,8$ & 0,0 & $-2,5$ \\
\hline median & 1,9 & 3,1 & 2,1 & 2,9 & 0,9 \\
\hline 75th Percentile & 3,1 & 3,9 & 3,9 & 4,3 & 2,3 \\
\hline 90th Percentile & 3,9 & 5,0 & 4,9 & 5,0 & 3,1 \\
\hline Standard-desviation & 3,3 & 3,5 & 3,5 & 3,4 & 3,5 \\
\hline Nr. Days min $<5^{\circ} \mathrm{C}$ & 40 & 38 & 38 & 38 & 41 \\
\hline Nr. Days $\min <0^{\circ} \mathrm{C}$ & 13 & 11 & 14 & 11 & 19 \\
\hline Nr. Days min $<-5^{\circ} \mathrm{C}$ & 2 & 2 & 3 & 2 & 3 \\
\hline
\end{tabular}

\begin{tabular}{|c|c|c|c|}
\hline \multirow{3}{*}{$\begin{array}{l}\text { ASE Zêzere } \\
1080 \mathrm{~m} \\
\end{array}$} & \multirow{3}{*}{$\begin{array}{c}\text { Candieira } \\
1420 \mathrm{~m}\end{array}$} & \multicolumn{2}{|l|}{ VALLEY SITES } \\
\hline & & Covão Cimeiro & Curral da Nave \\
\hline & & $1620 \mathrm{~m}$ & $1425 \mathrm{~m}$ \\
\hline$-0,6$ & $-4,0$ & $-2,0$ & $-3,4$ \\
\hline 6,2 & 4,6 & 5,0 & 3,5 \\
\hline$-6,7$ & $-12,9$ & $-14,6$ & $-11,8$ \\
\hline$-4,9$ & $-9,2$ & $-7,2$ & $-8,7$ \\
\hline$-3,5$ & $-7,2$ & $-4,9$ & $-6,0$ \\
\hline 0,1 & $-3,3$ & $-1,8$ & $-2,7$ \\
\hline 1,9 & $-1,4$ & 1,8 & $-0,7$ \\
\hline 3,4 & 1,4 & 3,5 & 0,3 \\
\hline 3,4 & 4,2 & 4,5 & 3,6 \\
\hline 39 & 42 & 42 & 42 \\
\hline 21 & 36 & 26 & 36 \\
\hline 3 & 17 & 10 & 11 \\
\hline
\end{tabular}

CLUSTER 2 PLATEAU / MOUNTAIN TOP SITES Alto Pedrice Cant. Gordo Fraga Penas Piornal Poios Brancos \begin{tabular}{cccc} 
ASE Zêzere & Candieira & $\begin{array}{c}\text { VALLEY SITES } \\
\text { Covão Cimeiro }\end{array}$ & $\begin{array}{c}\text { Curral da Nave } \\
1080 \mathrm{~m}\end{array}$ \\
$1420 \mathrm{~m}$ & $1620 \mathrm{~m}$ & $1425 \mathrm{~m}$ \\
\hline 2,2 & 1,3 & 0,4 & 0,2 \\
8,8 & 8,0 & 6,9 & 6,2 \\
$-5,8$ & $-9,7$ & $-7,7$ & $-6,7$
\end{tabular} Average Temp. ${ }^{\circ} \mathrm{C}$
Abs. Max. Temp. ${ }^{\circ} \mathrm{C}$ Abs. Min. Temp ${ }^{\circ} \mathrm{C}$ Abs. Min. Temp. ${ }^{\circ} \mathrm{C} \quad-7,2 \quad-7,5$ \begin{tabular}{ccc}
$1630 \mathrm{~m}$ & $1750 \mathrm{~m}$ & $1675 \mathrm{~m}$ \\
\hline 0,3 & $-0,2$ & $-1,0$
\end{tabular}

10th Percentile 25th Percentile

median

75th Percentil 90th Percentile

$\begin{array}{ll}-5,3 & -5,9 \\ -2,7 & -3,5\end{array}$

$-5,3$
$-2,7$
0,7

0,7

$\begin{array}{ll}3,0 & 2,7 \\ 4,3 & 3,9\end{array}$

$\begin{array}{lll}3,8 & 3,8\end{array}$

Nr. Days $\min <5^{\circ} \mathrm{C}$

Nr. Days $\min <0^{\circ} \mathrm{C}$

Nr. Days $\min <-5^{\circ} \mathrm{C}$

48
23

\section{RESULTS}

In the total data set (cluster 1 and 2 events) median temperatures at 7UTC are not too different (table II). Local climate influences are mitigated within the averages reflecting the general regional climatic conditions. This should be accounted for when analysing the average minimum temperatures in other areas, where fewer data are available. 
The absolute maximum temperatures at 7 UTC are very similar in top and valley sites, with a difference of only some $2^{\circ} \mathrm{C}$ (from $6.2^{\circ} \mathrm{C}$ to $8.8^{\circ} \mathrm{C}$, table II). The same cannot be stated for the absolute minimum temperatures, with differences up to $7^{\circ} \mathrm{C}$ (from $-14.6^{\circ} \mathrm{C}$ to $-7.2^{\circ} \mathrm{C}$ ). In $50 \%$ of the days, the temperatures at 7 UTC were $c a .3^{\circ} \mathrm{C}$ higher in the interfluves than in the valley sites. It is also interesting to note that the number of 'very cold' mornings (temperature at 7 UTC $<-5^{\circ} \mathrm{C}$ ) is much higher in valley sites ( 20 at Candieira and 8 at Piornal, for example). A significant result is that the ASE Zêzere site shows higher temperatures than the other valley sites, due to its lower altitude.

Mean temperatures differences between Piornal and the other stations for the 7 UTC obtained within the k-means classification are plotted in fig. 3 and show the opposite behaviour of the 2 calculated clusters (the lines are nearly symmetrical). Average temperatures are higher in cluster 2 events. In cluster 1 (46\% of the days) the lowest averages correspond to the valley sites, while in cluster 2 (54\% of the days), altitude is the main controlling factor and temperature does not depend on topographical position.

During the days included in cluster 1, temperature is lower in valley bottoms than on tops, especially at the highest sites (fig. 4). For example, the temperature in Candieira, a site located in a valley bottom at 1,420 m ASL, is

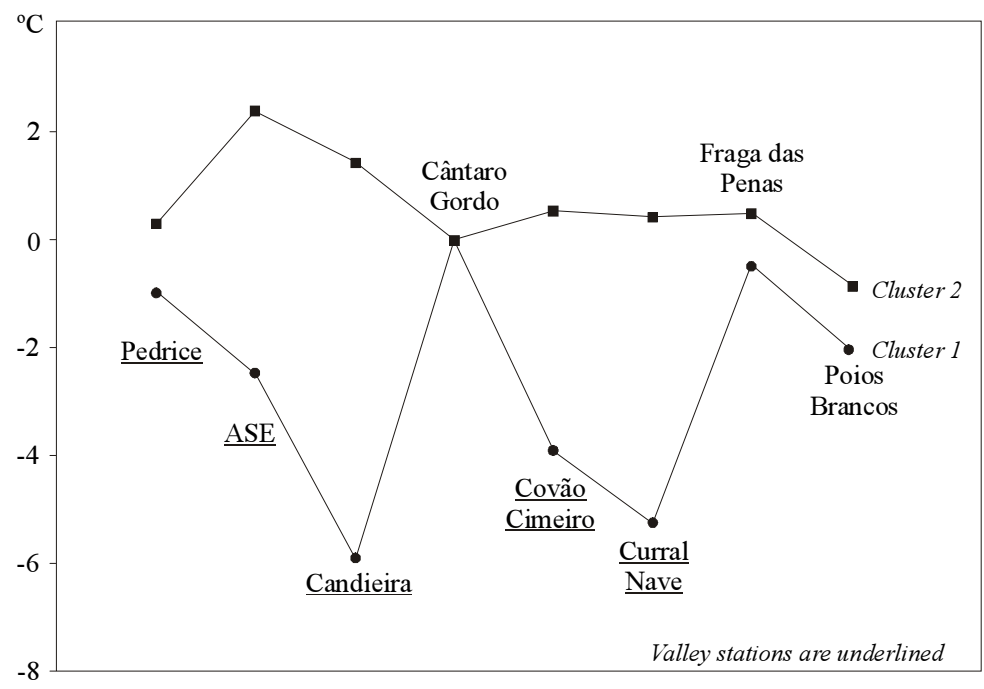

FIG. 3 - Mean temperature differences between Piornal and every other station for cluster 1 and 2 . In cluster 1 the differences are negative in the valley sites and they are positive in cluster 2

FIG. 3 - Média da diferença de temperatura dos postos de medição ao Piornal para os clusters 1 e 2. No cluster 1 as diferenças são negativas para locais de fundo de vale, enquanto no cluster 2 são positivas. 

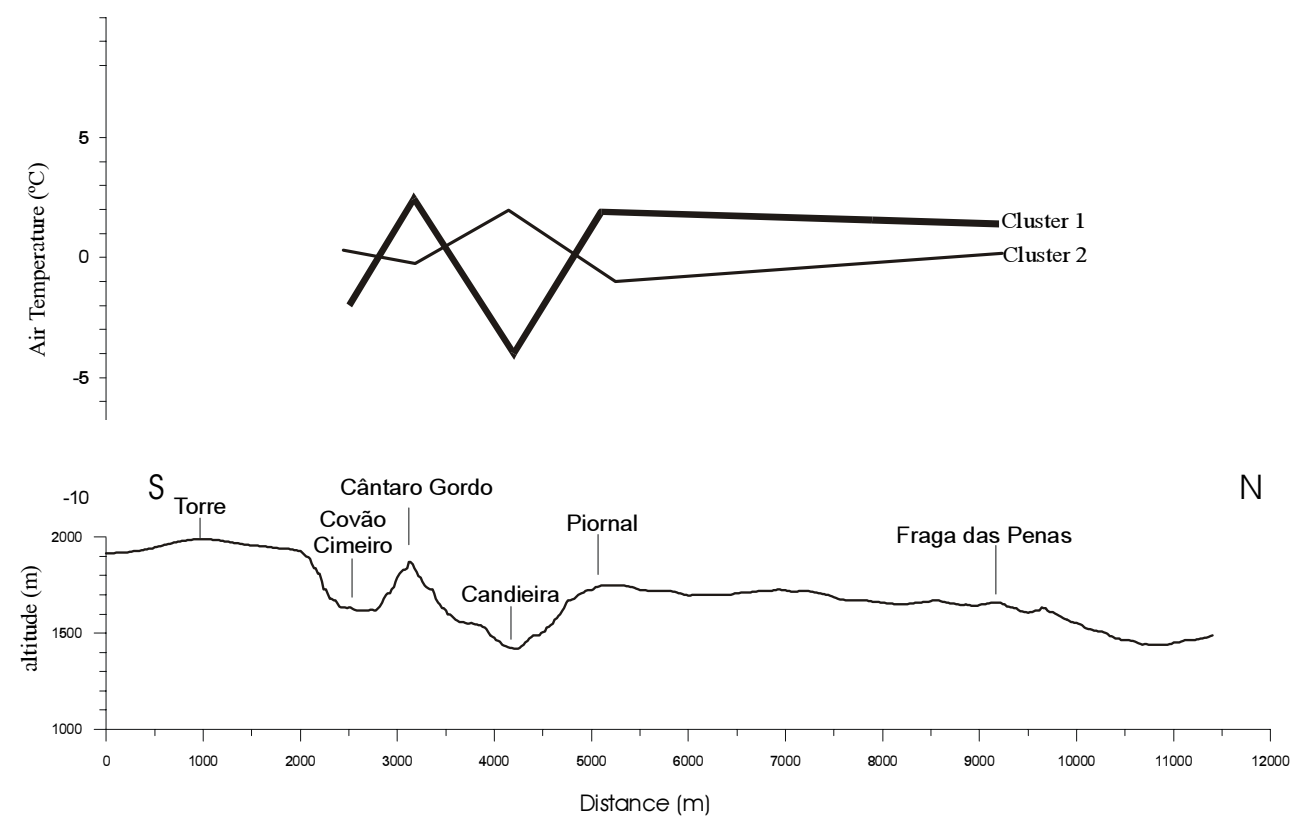

Fig. 4 - Cross-section between Covão Cimeiro and Fraga das Penas and mean temperatures during cluster 1 and 2 events

FIG. 4-Perfis topográfico e térmico (temperaturas médias) entre o Covão Cimeiro e a Fraga das Pena, em episódios classificados no cluster 1 e 2

frequently $6^{\circ} \mathrm{C}$ lower than in the Cântaro Gordo site, an adjacent ridge at 1,875 m ASL; however, the ASE Zêzere site, a valley floor at 1,080 m ASL, presents smaller differences when compared to the top and ridge localities (table II). This latter case is probably related to cold air drainage nocturnal cycles (NAKAMURA, 1976; LopEs, 1998). Even in small concave sites, like the small and wide valleys in the plateaus, the cold air drainage may lead to very significant differences in air temperature when compared to adjacent interfluves. The Curral da Nave site, a small depression in the plateau, reflects this kind of behaviour (table III). It is also interesting to note that in cluster 1 the number of days with temperatures below $0^{\circ} \mathrm{C}$ at 7 UTC is much larger in valley sites than in the higher top and ridge sites (up to 36 at Curral da Nave, versus 11 at Piornal). This is because the stable atmospheric conditions occurrying during the winter months in Portugal correspond generally to the coldest events, especially in what respects to the minima (Ferreira and Ferreira, 1983; Ramos, 1986 and Ventura, 1988). The percentiles (table II) indicate that the difference between temperatures in interfluves and valleys sites is higher in the lower percentiles (10th, 25th and 50th - median), showing that the colder events present more efficient cold air drainage conditions. 


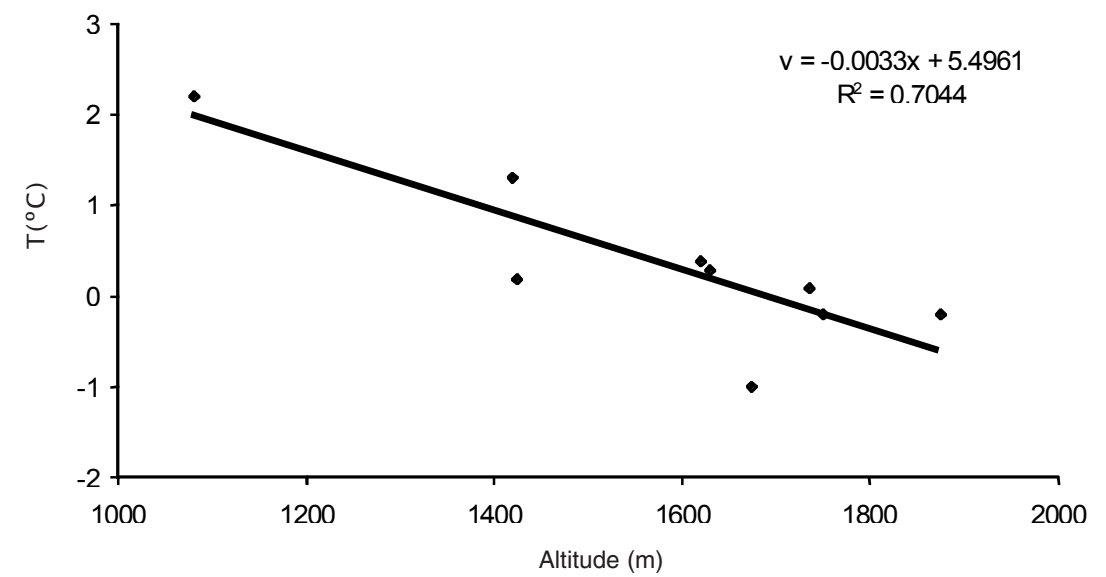

FIG. 5 - Best-fit regression between mean air temperatures during cluster 2 events and altitude of the measurement sites

FIG. 5 - Regressão entre as temperaturas médias do ar registadas em episódios classificados no cluster 2 e a altitude das estações

The days classified in cluster 2 are usually warmer than those in cluster 1 (fig. 3). The averages are lower in the interfluves than in the valleys reflecting a decrease of $-0.33^{\circ} \mathrm{C} / 100 \mathrm{~m}$. The negative lapse rate with altitude is the main controlling factor on the temperature pattern (fig. 5).

Daily synoptical charts and data from the meteorological station of the

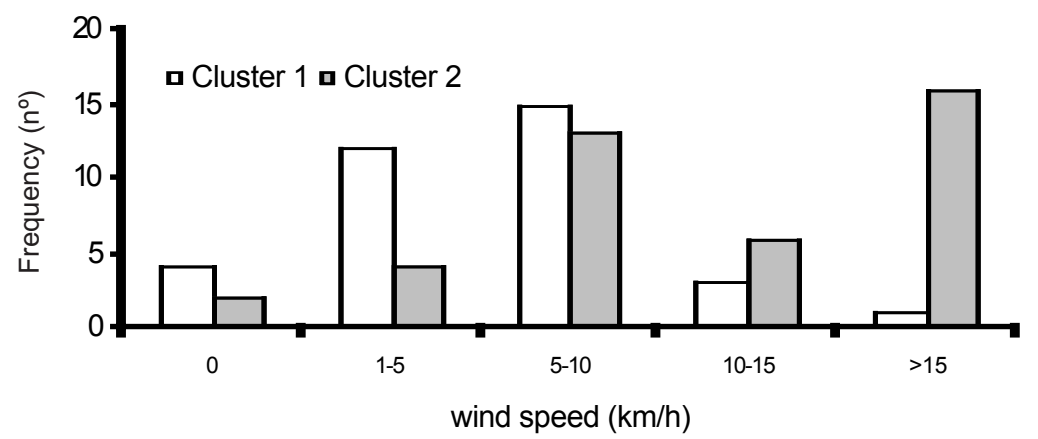

FIG. 6 - Wind speed in cluster 1 and 2 events in the winter of 1999/2000 in Penhas Douradas station

FIG. 6 - Velocidade do vento em situações de cluster 1 e 2 no Inverno de 1999/2000 na estação da Penhas Douradas. 
Instituto de Meteorologia located in Penhas Douradas (1,360 m ASL) were used to study the inter-cluster differences. However, the synoptic classification was not conclusive for the present purpose and a more detailed approach is being undertaken on weather types. At the local scale, among other controlling factors the analysis of wind speed and cloudiness gave better results.

The wind speed recorded at Penhas Douradas at 6 UTC was used to evaluate the stability conditions near the ground (fig. 6). The data suggest that with stronger wind the mixing is more significant and therefore cold air drainage conditions are not attained. The strongest winds are generally related to cluster 2 days and the lightest ones to stable cluster 1 events. A remarkable threshold seems to be the speed-class $5-10 \mathrm{~km} / \mathrm{h}$. It probably marks the boundary between stable and unstable conditions near the surface.

\section{FINAL REMARKS}

The results presented above are only a small part of a large database resulting from the detailed monitoring of air temperatures in the Estrela range. Their detailed analysis is expected to become a major contribution for the study of the local climate of the area. This first study shows a marked distinction between minimum air temperatures in stable and unstable conditions. In the former, cold air drainage is proeminent and the valleys show much lower temperatures than the interfluves. In the latter the unstable conditions generate a mixing of the air responsible for a general lowering of the temperature with increasing altitude.

The results presented here agree with the theoretical and empirical background proposed by several authors (GEIGER, 1961; Yoshino, 1975; BARRY, 1992). Furthermore this first study of the local climate of the Serra da Estrela shows that extremely low temperatures may occur in relatively low sites in Portugal. A good example is the temperature of $-17^{\circ} \mathrm{C}$ recorded in the Covão Cimeiro cirque. It also emphasises the importance of this kind of research in the framework of planning of regional infrastructures and related environmental impact assessment studies.

\section{ACKNOWLEDGEMENTS}

The authors are thankful to the guards of the Natural Park of the Serra da Estrela for the help in field work and specially to Mr. José Maria Saraiva for the invaluable support in the installation and maintenance of the stations; the SOS Estrela mountain rescue team (Associação Cultural Amigos da Serra da Estrela) for the help in winter data collection; Prof. Miguel Ramos for the collaboration in the design of the dataloggers; Dr. Henrique Andrade for the suggestions on the station frames; António Eanes, Pedro Mora and Dr. Mário Neves for the help 
in the installation of the data loggers; as well as the referees for their advices and helpful criticism.

This research was funded by Fundação para a Ciência e a Tecnologia in the framework of the project «Processos geomorfológicos e biofísicos e unidades de paisagem em ambientes de montanha mediterrânea. Aplicação à Serra da Estrela» (Praxis/C/CTE/11153/1988).

\section{REFERENCES}

Alcoforado, M. J. (1993) - O clima da região de Lisboa. Contrastes e regimes térmicos. Mem. $\mathrm{N}^{\mathrm{o}} 15$, C.E.G., Lisboa: 347 p.

BARRY, R.G. (1992) - Mountain weather \& climate. Routledge, London: 402p.

Daveau, S.; Coelho, C.; Costa, V. G. \& Carvalho, L. (1977) - Répartition et rythme des précipitations au Portugal, Memórias do Centro de Estudos Geográficos, 3, Lisboa.

Ferreira, A.B.; Ferreira, D. B. (1983) - A seca de 1980-81 em Portugal - causas meteorológicas e tipos de tempo. Finisterra- Revista Portuguesa de Geografia, Lisboa, XVIII (35): 27-63.

GeIGer, R. (1961) - Manual de Microclimatologia, F.C.G., Lisboa.

HaRTigan, J. A. (1975) - Clustering algorithms. New York, Wiley.

JANSEN, J.; SEQUEIRA, M.P.S.M. (1999) - The vegetation of shallow waters and seasonally-inundated habitats (Littorelletea and Isoeto-Nanojuncetea) in the higher parts of the Serra da Estrela, Portugal. Mitt. d. Badischen Landesver. f. Naturkunde, N.F. 17(2): 449-462.

LOPES, A (1998) - Contrastes térmicos nocturnos e acumulação de ar frio em áreas urbanas do Sul da Península de Lisboa. Finisterra - Revista Portuguesa de Geografia, Lisboa, XXXIII (66):25-40.

NAKAmuRA, K. (1989) - Local climatological study of the nocturnal cold air drainage on the mountain slope. Bulletin of Dotho University, General Education, 8: 53-145.

Ramos, C. (1986) - Tipos de anticiclones e ritmo climático de Portugal. L.A.G.F., rel. n. ${ }^{0}$ 25, C.E.G., Lisboa.

Ventura, J. E. (1988) - Temperaturas máximas e mínimas em Portugal continental. Tentativa de representação cartográfica. L.A.G.F., rel. n. ${ }^{\circ} 28$, C.E.G., Lisbon.

VIEIRA, G.T.; MoRA, C. (1998) - General characteristics of the climate of Serra da Estrela, In G.T. Vieira (ed.), Glacial and Periglacial geomorphology of the Serra da Estrela. Guidebook of the field-trip of the IGU Commission on Climate Change and Periglacial Environments, CEG and Department of Geography, Lisboa: 26-32. 
Vieira, G.T.; Mora, C.; Ramos, M. (2000) - Registadores automáticos de baixo-custo para a monitorização de temperaturas do ar, da rocha e do solo. Finisterra-Revista Portuguesa de Geografia, Lisboa, XXXV (69); 139-148.

Yoshino, M.M. (1975)-Climate in a small area. An introduction to local Meteorology. University of Tokyo Press, Tokyo. 